\title{
Keragaman Morfologi dan Molekuler Lasiodiplodia theobromae dari Tanaman Jeruk, Kakao, Karet, Manggis, dan Pisang
}

\author{
Morphological and Molecular Diversity of Lasiodiplodia theobromae \\ Isolated from Citrus, Cocoa, Rubber, Banana and Mangosteen Plants
}

\author{
Fitri Kemala Sandra, Yayu Siti Nurhasanah, Kikin Hamzah Mutaqin*, \\ Suryo Wiyono, Efi Toding Tondok \\ Institut Pertanian Bogor, Bogor 16680
}

\begin{abstract}
ABSTRAK
Lasiodiplodia theobromae adalah cendawan patogen penting dan kosmopolitan di daerah tropis dan subtropis. Kisaran tanaman inangnya sangat luas, termasuk komoditas bernilai ekonomi tinggi di Indonesia, seperti jeruk, kakao, karet, pisang, dan manggis. Keragaman intraspesies galur cendawan hasil isolasi lima tanaman diamati berdasarkan pada ciri morfologi dan marka molekuler RAPD-PCR. Keragaman intraspesies ditunjukkan dari perbedaan laju pertumbuhan vegetatif koloni pada medium agar-agar dekstrosa kentang serta kemampuan menghasilkan struktur reproduksi. Galur cendawan asal jeruk, karet, dan pisang tumbuh cepat dan menghasilkan piknidium dan konidum pada medium agaragar dekstrosa kentang dan medium agar-agar air yang dimodifikasi, sedangkan galur asal kakao dan manggis tumbuh lambat dan hanya dapat menghasilkan struktur reproduksi pada medium agar-agar air yang dimodifikasi. Keragaman antargalur dalam spesies L. theobromae ditunjukkan oleh perbedaan nyata morfologi struktur reproduksi. Konidium muda (tanpa sekat) memiliki panjang berkisar 13.5-25.7 $\mu \mathrm{m}$, lebar 8.1-14.0 $\mu \mathrm{m}$, dan nisbah panjang/lebar 1.5-2.2; sedangkan untuk konidium matang (bersekat) memiliki panjang 15.4-23.6 $\mu \mathrm{m}$, lebar 10.7-12.8 $\mu \mathrm{m}$, nisbah panjang/lebar 1.4-1.9. Walaupun ukuran konidium antargalur menunjukkan perbedaan, namun masih dalam kisaran ciri ukuran spesies $L$. theobromae. Profil fragmen DNA RAPD-PCR menggunakan primer tunggal OPB-01 maupun OPB-07 masing-masing menghasilkan jumlah dan ukuran pita DNA yang berbeda-beda antara lima galur sehingga menunjukkan adanya keragaman molekuler antargalur dalam satu spesies tersebut.
\end{abstract}

Kata kunci: Botryodiplodia theobromae, keragaman intraspesies, konidium, piknidium, profil RAPD-PCR

\begin{abstract}
The fungus Lasiodiplodia theobromae is an important and cosmopolitan pathogen in the tropics and subtropics. The range of host plants is very wide, including economic commodities in Indonesia, i.e. citrus, cocoa, rubber, banana and mangosteen. The intraspecies diversity of fungi isolates from those five plants from different provinces in Indonesia was observed based on the morphological characteristics and molecular markers of RAPD-PCR. The intraspecies diversity was shown from the vegetative growth rate of the colonies on PDA as a base medium and the ability to produce reproductive structures. The fungal isolates from citrus, rubber and banana were able to grow faster and produce pycnidium and conidium in both PDA and modified-WA medium, while the cocoa and mangosteen isolates grow slower and only could produce these reproductive structures in the WA medium. The diversity between isolates
\end{abstract}

\footnotetext{
*Alamat penulis korespondensi: Departemen Proteksi Tanaman, Institut Pertanian Bogor, Jalan Kamper Kampus IPB Dramaga, Bogor 16680

Tel/Faks: 0251-8629364/0251-8629362; Surel: kmutaqin@apps.ipb.ac.id
} 
in L. theobromae species was indicated by the morphological difference of the reproductive structures. Young conidium (aseptate) has a length ranging from 13.5-25.7 $\mu \mathrm{m}$, width $8.1-14.0 \mu \mathrm{m}$, and length/ width ratio 1.5-2.2; while for mature conidium (septate) 15.4-23.6 $\mu \mathrm{m}$ long, 10.7-12.8 $\mu \mathrm{m}$ wide, length/ width ratio 1.4-1.9. Although the conidium sizes between isolates showed differences, they were still within the range of size of the $L$. theobromae species. The profile of RAPD-PCR DNA fragments using single primers OPB-01 and OPB-07 each resulted in different numbers and sizes of DNA bands between the five isolates, thus indicating the existence of molecular diversity between isolates within the same species.

Key words: Botryodiplodia theobromae, conidium, intraspecies diversity, pycnidium, RAPD-PCR profile

\section{PENDAHULUAN}

\section{Lasiodiplodia theobromae (Sinonim:} Botryodiplodia theobromae) adalah cendawan patogen penting secara ekonomi pada berbagai komoditas tanaman perkebunan, hortikultura, dan pangan di wilayah tropis maupun subtropis. Patogen ini bersifat oportunistik dalam menimbulkan penyakit dengan memanfaatkan luka atau jaringan nekrotik terutama pada organ tanaman yang berdaging atau berkayu, seperti busuk buah, hawar daun, busuk ujung batang, gumosis. kanker batang dan mati ujung (Barkai-Golan 2001; Picos-Muñoz 2015; Rossman et al. 2017; Karunanayake dan Adikaram 2020). Cendawan ini memiliki kisaran tanaman inang sangat luas, yaitu sekitar 500 spesies tanaman (Punithalingam 1980; Vitoria et al. 2012), termasuk jeruk, kakao, karet, manggis, dan pisang (Goos et al. 1961; Sangchote dan Pongpisutta 1998; Kannan et al. 2010; Zhang 2014; Febbiyanti et al. 2019). Spesies ini dikenal juga sebagai cendawan yang dapat hidup sebagai endofit tanpa menyebabkan gejala pada tanaman (Mohali et al. 2005; Salvatore et al. 2020).

Keberadaan cendawan yang kosmopolitan dengan kisaran tanaman inang yang sangat luas kemungkinan memiliki keragaman yang tinggi dalam spesies, bahkan antarspesies dalam genus Lasiodiplodia. Identifikasi $L$. theobromae sebagai anggota dalam famili Botryosphaeriaceae selama berpuluh tahun didasarkan pada ciri morfologi. Penggunaan metode molekuler runutan DNA telah membawa perubahan dalam sistematika dan taksonomi (Bautista-Cruz et al. 2010; Slippers et al. 2013). Burgess (2006) membuktikan ada tiga spesies baru dari Lasiodiplodia berdasarkan perbandingan ciri morfologi dan runutan DNA.

Di Indonesia, keragaman intraspesies $L$. theobromae atau spesies Lasiodiplodia dari pelbagai tanaman inang dan lokasi berbeda belum banyak dilaporkan. Penelitian ini bertujuan memperoleh keragaman galur cendawan $L$. theobromae dari tanaman inang jeruk, kakao, karet, manggis, dan pisang berdasarkan ciri gejala, morfologi, dan marka molekuler RAPD-PCR.

\section{BAHAN DAN METODE}

Galur L. theobromae yang diteliti merupakan koleksi biakan Laboratorium Mikologi Tumbuhan, Fakultas Pertanian, IPB University. Koleksi biakan tersebut berasal dari tanaman sakit pada jeruk (Jember, Jawa Timur), karet (Pematang Siantar, Sumatera Utara), pisang (Bogor, Jawa Barat), manggis (Bukittinggi, Sumatera Barat), dan kakao (Taman Nasional Lorelindu, Sulawesi Tengah) yang disimpan dalam medium agar-agar dekstrosa kentang (ADK).

\section{Pengamatan Morfologi Koloni dan Strusktur Reproduktif Lasiodiplodia theobromae}

Koleksi biakan diremajakan pada medium ADK, kemudian ditanam pada tiga cawan berdiameter $9 \mathrm{~cm}$ untuk setiap galur. Pengamatan pertumbuhan, bentuk, dan warna koloni dilakukan setiap 12 jam selama empat hari. Setiap galur cendawan juga ditanam pada medium agaragar air (AA) yang dimodifikasi dengan 
penambahan potongan jerami padi steril untuk galur dari jeruk, kakao, karet, dan pisang, serta penambahan kulit manggis untuk galur asal manggis. Piknidium, konidium muda, dan konidium dewasa yang tumbuh pada medium AA diamati pembentukan dan dimensinya menggunakan mikroskop cahaya dan dipotret menggunakan kamera digital.

\section{Marka Molekuler RAPD-PCR}

Lima galur L. theobromae diremajakan dalam medium kaldu dekstrosa kentang (KDK) selama 72 jam. DNA diekstraksi dari miselium yang tumbuh dalam medium KDK (Moller et al. 1992) untuk menyediakan templat DNA dalam teknik random amplified polymorphisms DNA-polymerase chain reaction (RAPD-PCR).

Reaksi RAPD-PCR menggunakan masing-masing primer tunggal OPB-01 (5'-GTTTCGCTCC-3) dan OPB-07 (5'-GGTGACGCAG-3') dalam total volume $25 \mu \mathrm{L}$. Sebanyak $16.2 \mu \mathrm{L}$ akuades dicampur dengan $2.5 \mu \mathrm{L}$ bufer PCR $\mathrm{Mg}^{2+}, 0.5 \mu \mathrm{L}$ $\mathrm{MgCl}_{2} 25 \mathrm{mM}, 2.5 \mu \mathrm{L}$ dNTPs $2 \mathrm{mM}, 1 \mu \mathrm{L}$ primer $10 \mu \mathrm{M}, 0.5 \mu \mathrm{L}$ Taq DNA $5 \mathrm{U} \mu \mathrm{L}^{-1}$, dan $2 \mu \mathrm{L}$ DNA templat. Reaksi RAPD-PCR dengan mesin GeneAmp 9700 PCR system dilakukan sebanyak 45 siklus yang terdiri atas tahap denaturasi $94^{\circ} \mathrm{C}, 2$ menit 30 detik; pemanjangan $40{ }^{\circ} \mathrm{C}, 1$ menit; dan sintesis $72{ }^{\circ} \mathrm{C}$, 1 menit; serta ekstensi akhir $72{ }^{\circ} \mathrm{C}$ selama 7 menit. Hasil amplifikasi RAPD-PCR diseparasi melalui elektroforesis gel agarosa $1.5 \%$ dalam bufer TAE $1 \mathrm{X}$ mengandung $10 \mu \mathrm{L}$ EtBr, pada tegangan 75 volt DC selama 60 menit.

\section{Analisis}

Data morfologi struktur $L$. theobromae dianalisis ragam (Anova) dan perbandingan nilai tengah menggunakan piranti Statistical Analysis Software (SAS) versi 9.0.

\section{HASIL}

Semua galur $L$. theobromae yang diremajakan pada medium ADK menghasilkan pertumbuhan soma (miselium) yang relatif cepat, yaitu di bawah 96 jam. Koloni miselium masing-masing galur memiliki warna bervariasi dari putih keabu-abuan hingga abu-abu (Gambar 1 dan 2). Pertumbuhan miselium lebih cepat ditunjukkan oleh galur asal pisang, karet, dan jeruk dengan fase log yang berlangsung pada jam ke-36 hingga 42 dilanjutkan fase stasioner, sedangkan untuk kakao fase log berlangsung pada jam ke-60 hingga 72 , bahkan yang paling lambat ialah kakao pada jam ke-84.

Pertumbuhan soma pada medium ADK akan membentuk struktur reproduksinya berturut-turut piknidium, konidium muda, dan konidium dewasa. Struktur reproduksi ini dibentuk pada galur asal jeruk, karet, dan pisang, sedangkan galur asal kakao dan manggis tidak terbentuk. Rentang waktu pembentukan piknidium hingga konidium dewasa pada galur jeruk, karet, dan pisang bervariasi. Galur L. theobromae asal jeruk dan pisang lebih cepat membentuk struktur reproduksi pada medium ADK dibandingkan dengan galur yang berasal dari karet (Tabel 1).

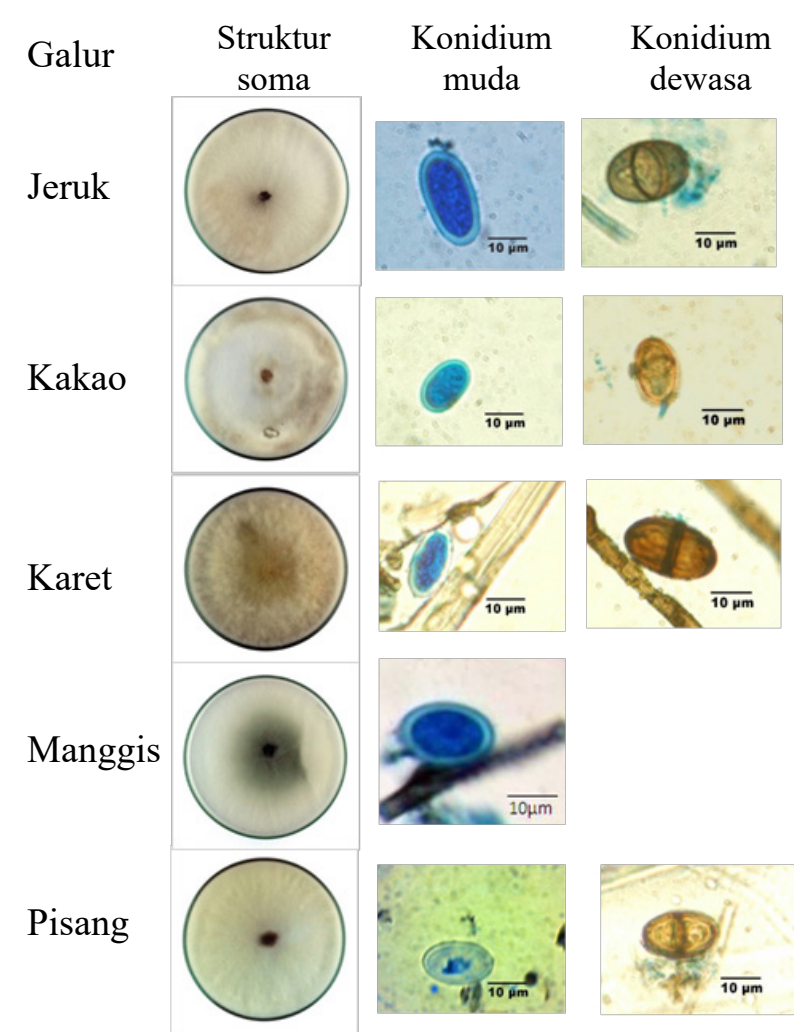

Gambar 1 Lima galur Lasiodiplodia theobromae: struktur soma (massa miselium) pada medium agar-agar dekstrosa kentang dan struktur reproduksinya. 


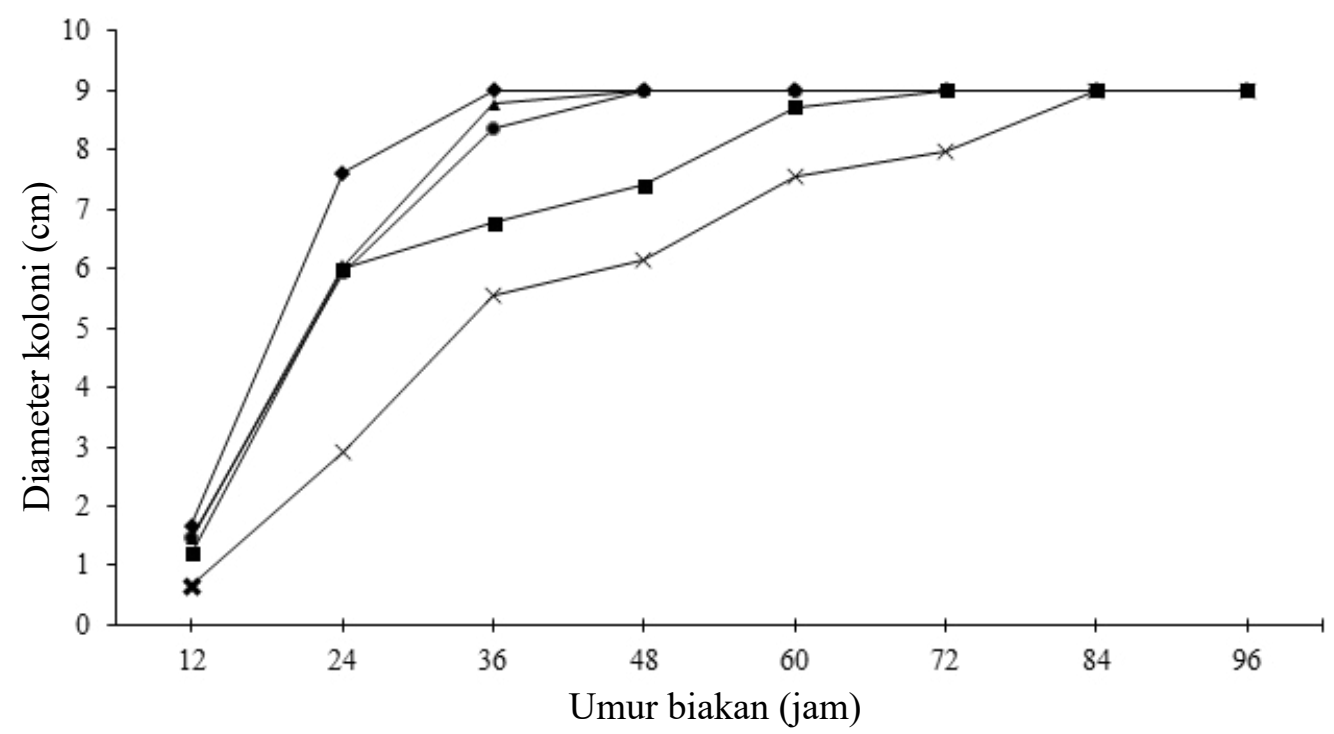

Gambar 2 Pertumbuhan koloni (massa miselium) lima galur Lasiodiplodia theobromae yang berasal dari jeruk $(\rightarrow-)$, kakao $(\bullet-)$, karet $(\bullet)$, manggis $(\leftarrow)$ dan pisang $(\bullet \bullet)$ pada medium ADK selama 96 jam.

Pembentukan struktur reproduksi seluruh galur L. theobromae terjadi pada medium AA yang dimodifikasi dengan penambahan jerami padi untuk jeruk, kakao, karet, dan pisang, serta penambahan kulit manggis untuk galur asal manggis (Tabel 1). Rentang waktu pembentukan piknidium hingga konidium dewasa untuk jeruk, karet, dan pisang pada medium AA yang dimodifikasi ini lebih cepat dan pendek dibandingkan dengan pada medium ADK, bahkan galur asal karet menjadi yang tercepat dan terpendek. Galur asal kakao yang pada ADK tidak mampu membentuk struktur reproduksi, pada medium AA yang dimodifikasi terinduksi untuk membentuknya, yaitu piknidium, konidium muda, dan konidium dewasa. Galur manggis pun mampu membentuk piknidium, namun hanya sampai konidium muda.

Perbandingan dimensi struktur reproduksi konidium muda dan matang $L$. theobromae bervariasi (Tabel 2). Ukuran panjang konidium muda menunjukkan perbedaan nyata dari yang tertinggi berturut-turut ialah galur asal jeruk, karet, kakao, pisang, dan manggis, sedangkan ukuran lebar dari yang tertinggi ialah kakao, karet, jeruk, pisang, dan manggis. Nisbah panjang/lebar konidium muda yang menjauhi nilai 1 menunjukkan semakin lonjongnya struktur tersebut, sedangkan jika mendekati nilai 1 maka semakin membulat. Tingkat kelonjongan konidium muda berbeda nyata antargalur, berturut-turut dari yang paling lonjong ialah jeruk, kakao, karet, pisang, dan manggis. Konidium muda relatif hialin sehingga ketebalan dinding sel konidium muda dapat diukur. Ketebalan dinding ini juga menunjukkan perbedaan nyata antargalur, berturut-turut dari yang paling tebal ialah kakao, karet, pisang, manggis, dan jeruk.

Konidium dewasa, kecuali untuk galur asal manggis, dapat diukur panjang, lebar, dan nisbah panjang/lebarnya, namun tidak dapat dilakukan untuk ketebalan dinding sel karena warnanya yang gelap (Tabel 2). Panjang, lebar, dan nisbah panjang/lebar konidium dewasa menunjukkan perbedaan nyata antara beberapa galur, berturut-turut dari yang terpanjang ialah jeruk, karet, pisang, dan kakao, sedangkan untuk ukuran terlebar berturut-turut jeruk, pisang, karet, dan kakao, serta dari yang terlonjong ialah karet, jeruk, pisang, dan kakao.

Profil fragmen DNA amplikon hasil RAPD-PCR baik menggunakan primer OPB01 maupun OPB-07 dari masing-masing $L$. theobromae galur asal kelima tanaman inang, menunjukkan perbedaaan satu dengan yang lainnya baik dari jumlah fragmen maupun masing-masing ukuran fragmen DNA 
Tabel 1 Pembentukan piknidium, konidium muda, dan konidium dewasa lima galur Lasiodiplodia theobromae pada medium agar-agar dekstrosa kentang dan agar-agar air yang dimodifikasi

\begin{tabular}{|c|c|c|c|c|c|c|}
\hline \multirow{3}{*}{ Asal isolat } & \multicolumn{6}{|c|}{ Waktu (HST) yang diperlukan untuk membentuk struktur pada medium } \\
\hline & \multicolumn{3}{|c|}{ ADK } & \multicolumn{3}{|c|}{$\mathrm{AA}+$ jerami atau kulit manggis } \\
\hline & Piknidium & $\begin{array}{l}\text { Konidium } \\
\text { muda }\end{array}$ & $\begin{array}{c}\text { Konidium } \\
\text { dewasa }\end{array}$ & Piknidium & $\begin{array}{l}\text { Konidium } \\
\text { muda }\end{array}$ & $\begin{array}{c}\text { Konidium } \\
\text { dewasa }\end{array}$ \\
\hline Jeruk & 17 & 17 & 22 & 13 & 13 & 21 \\
\hline Kakao & - & - & - & 20 & 20 & 22 \\
\hline Karet & 32 & 39 & 48 & 13 & 13 & 19 \\
\hline Pisang & 17 & 18 & 22 & 17 & 17 & 23 \\
\hline Manggis & - & - & - & 34 & 34 & - \\
\hline
\end{tabular}

Keterangan: HST, hari setelah tanam; ADK, agar-agar dekstrosa kentang; AA, agar-agar air; dan (-), tidak terbentuk.

Tabel 2 Perbandingan ukuran panjang, lebar, nisbah panjang/lebar, dan ketebalan dinding konidium muda dan matang lima galur Lasiodiplodia theobromae

\begin{tabular}{lcccc}
\hline $\begin{array}{l}\text { Asal } \\
\text { L. theobromae }\end{array}$ & $\begin{array}{c}\text { Panjang } \\
(\mu \mathrm{m})\end{array}$ & $\begin{array}{c}\text { Lebar } \\
(\mu \mathrm{m})\end{array}$ & $\begin{array}{c}\text { Nisbah panjang/ } \\
\text { lebar }\end{array}$ & $\begin{array}{c}\text { Ketebalan dinding } \\
(\mu \mathrm{m})\end{array}$ \\
\hline Jeruk & $25.68 \pm 1.62 \mathrm{a}$ & $\begin{array}{c}11.95 \pm 1.44 \mathrm{~b} \\
\text { Konidium muda }\end{array}$ & $2.18 \pm 0.34 \mathrm{a}$ & $1.23 \pm 0.28 \mathrm{c}$ \\
Kakao & $23.26 \pm 0.53 \mathrm{~b}$ & $14.02 \pm 1.20 \mathrm{a}$ & $1.82 \pm 0.12 \mathrm{~b}$ & $1.91 \pm 0.15 \mathrm{a}$ \\
Karet & $24.77 \pm 1.80 \mathrm{ab}$ & $13.79 \pm 2.00 \mathrm{a}$ & $1.69 \pm 0.22 \mathrm{bc}$ & $1.80 \pm 0.40 \mathrm{a}$ \\
Pisang & $15.32 \pm 0.68 \mathrm{c}$ & $10.32 \pm 0.91 \mathrm{c}$ & $1.67 \pm 0.18 \mathrm{bc}$ & $1.52 \pm 0.17 \mathrm{~b}$ \\
Manggis & $13.45 \pm 2.08 \mathrm{~d}$ & $8.09 \pm 0.88 \mathrm{~d}$ & $1.50 \pm 0.36 \mathrm{c}$ & $1.34 \pm 0.21 \mathrm{bc}$ \\
\hline & & Konidium dewasa & \\
Jeruk & $23.63 \pm 2.26 \mathrm{a}$ & $12.83 \pm 1.10 \mathrm{a}$ & $1.86 \pm 0.31 \mathrm{a}$ & - \\
Kakao & $15.40 \pm 1.96 \mathrm{c}$ & $10.67 \pm 1.00 \mathrm{~b}$ & $1.44 \pm 0.12 \mathrm{~b}$ & - \\
Karet & $21.08 \pm 3.19 \mathrm{~b}$ & $11.39 \pm 1.45 \mathrm{~b}$ & $1.89 \pm 0.46 \mathrm{a}$ & - \\
Pisang & $19.32 \pm 1.98 \mathrm{~b}$ & $11.59 \pm 1.01 \mathrm{~b}$ & $1.68 \pm 0.21 \mathrm{ab}$ & - \\
\hline
\end{tabular}

Angka selajur yang diikuti huruf berbeda menunjukkan perbedaan nyata dengan uji selang berganda Duncan pada $\alpha$ 5\%.

(Gambar 3 dan Tabel 3). RAPD-PCR dengan primer OPB-01 menunjukkan galur $L$. theobromae dengan profil jumlah fragmen dari yang terbanyak beserta rentang ukuran fragmennya $(\mathrm{pb})$ ialah galur asal karet 7 fragmen (500-2072 pb), pisang 6 fragmen (500-2072 pb), jeruk dan kakao sama-sama 5 fragmen (500->2072 pb) namun tidak identik, dan manggis 3 fragmen (700-2072 pb). Sedangkan profil dengan primer OPB-07 ialah berturut-turut karet 8 fragmen $(800->2072 \mathrm{pb})$, pisang 7 fragmen $(800->2072 \mathrm{pb})$, manggis 4 fragmen (500->2072 pb) serta jeruk 3 fragmen (1200->2072 pb) dan kakao 3 fragmen $(800->2072 \mathrm{pb})$.

\section{PEMBAHASAN}

Pertumbuhan struktur soma (massa miselium) masing-masing galur L. theobromae pada medium ADK memiliki laju yang berbeda untuk mencapai diameter koloni maksimum dalam cawan petri. Galur asal pisang, karet, dan jeruk yang memiliki laju pertumbuhan cepat dan mampu meneruskan produksi struktur reproduksi piknidium, konidium muda (tanpa sekat), dan konidium dewasa (bersekat), sedangkan galur asal kakao dan manggis tidak mampu menghasilkan struktur reproduksi tersebut pada medium ADK. Produksi struktur reproduksi baik 

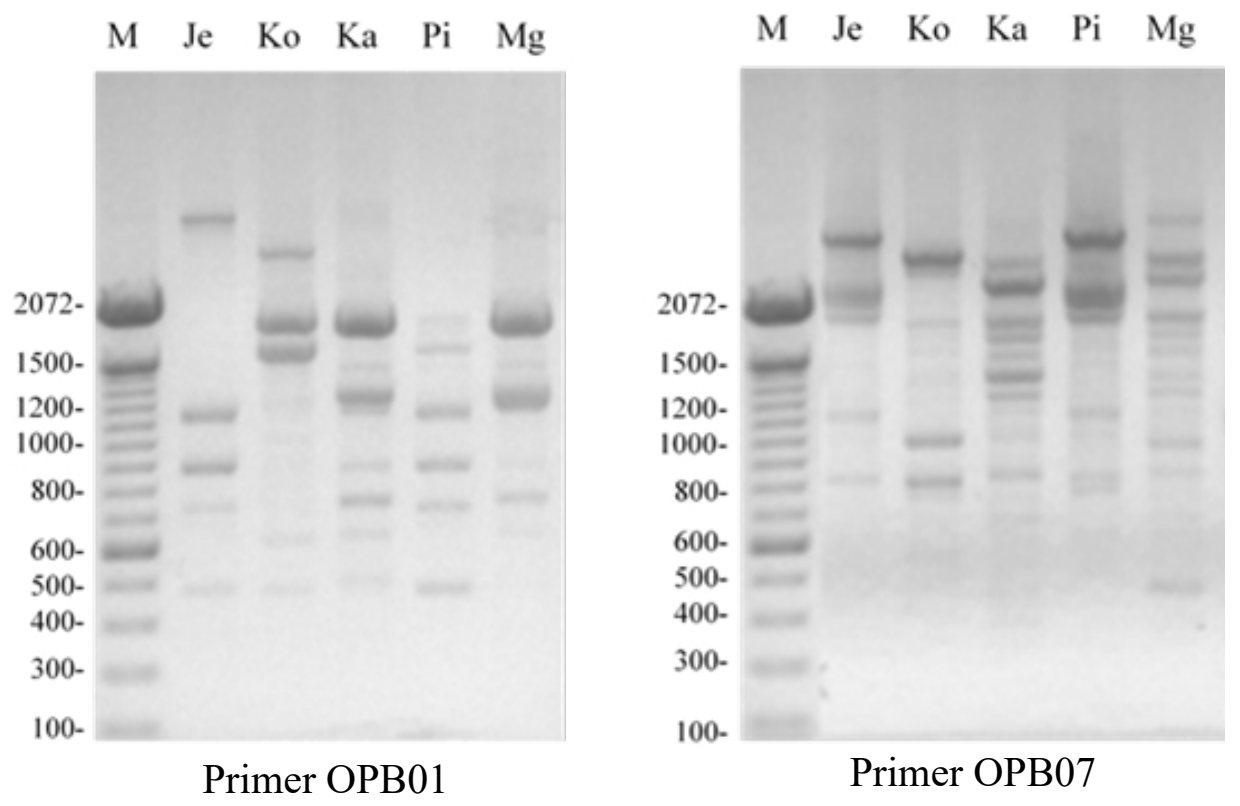

Gambar 3 Profil RAPD-PCR untuk lima galur Lasiodiplodia theobromae. M, Marker DNA ladder; Je, Jeruk; Ko, Kakao; Ka, Karet; Pi, Pisang; Mg, Manggis.

Tabel 3 Jumlah dan ukuran fragmen DNA hasil estimasi dari profil RAPD-PCR berdasarkan primer OPB-01 dan OPB-07 lima galur Lasiodiplodia theobromae

\begin{tabular}{|c|c|c|c|c|c|c|c|c|}
\hline \multirow{2}{*}{ L. theobromae } & \multicolumn{8}{|c|}{ Ukuran DNA fragmen ke- } \\
\hline & 1 & 2 & 3 & 4 & 5 & 6 & 7 & 8 \\
\hline \multicolumn{9}{|c|}{ OPB-01 (pb) } \\
\hline Jeruk & $>2072$ & 1200 & 900 & 700 & 500 & & & \\
\hline Kakao & $>2072$ & 2072 & 1500 & 600 & 500 & & & \\
\hline Karet & 2072 & 1500 & 1300 & 1200 & 900 & 600 & 500 & \\
\hline Pisang & 2072 & 1500 & 1200 & 900 & 700 & 500 & & \\
\hline Manggis & 2072 & 1200 & 700 & & & & & \\
\hline \multicolumn{9}{|c|}{ OPB-07 (pb) } \\
\hline Jeruk & $>2072$ & 2072 & 1200 & & & & & \\
\hline Kakao & $>2072$ & 1000 & 800 & & & & & \\
\hline Karet & $>2072$ & 2072 & 1700 & 1600 & 1500 & 1300 & 1200 & 800 \\
\hline Pisang & $>2072$ & 2072 & 1700 & 1100 & 1000 & 800 & & \\
\hline Manggis & $>2072$ & 1700 & 1000 & 500 & & & & \\
\hline
\end{tabular}

galur asal kakao dan manggis maupun tiga galur lainnya berhasil diinduksi menggunakan medium AA yang dimodifikasi. Kemampuan tumbuh yang berbeda tersebut menunjukkan adanya keragaman dalam spesies cendawan ini. Produksi struktur reproduktif $L$. theobromae pada medium buatan penting dalam identifikasi karena didasarkan pada morfologi struktur reproduksi ini, sementara cendawan seringkali gagal membentuknya. Griffiths (1967) melaporkan cendawan spesies ini dari tanaman inang tertentu seringkali harus ditumbuhkan dengan kondisi khusus, terutama pemberian nutrisi alami tambahan pada medium umum.

Morfologi dan dimensi struktur reproduksi piknidium dan konidium $L$. theobromae pada medium ADK maupun medium AA yang dimodifikasi merupakan penciri penting untuk menunjukkan keragaman cendawan ini. Perbedaan secara kualitatif (warna dan bentuk struktur) dan kuantitatif menjadi petunjuk terdapat keragaman intraspesies L. theobromae yang diisolasi dari tanaman inang maupun lokasi tanaman yang berbeda. Keragaman yang tinggi dalam spesies 
ditunjukkan dengan perbedaan yang nyata di antara lima galur dalam hal panjang, lebar, dan ketebalan dinding sel konidium muda (tanpa sekat) yang semuanya hialin serta panjang dan lebar konidium dewasa (bersekat) yang berwarna lebih gelap. Konsekuensi dari adanya keragaman dalam ukuran panjang dan lebar konidium ialah nisbah panjang/lebar yang juga beragam secara nyata di antara galur yang menentukan kecenderungan membulat atau lonjongnya konidium. Burgess et al. (2006) menggunakan ciri dimensi panjang $\times$ lebar dan nisbah panjang/lebar L. theobromae ialah 15$35 \mu \mathrm{m} \times 10-15 \mu \mathrm{m}$ dan 1.9, sedangkan spesies lain L. gonubiensis 28-39 $\mu \mathrm{m} \times 14-21 \mu \mathrm{m}$ dan 1.9, L. venezuelensis $26-33 \mu \mathrm{m} \times 12-15 \mu \mathrm{m}$ dan 2.1, L. crassispora 27-33 $\mu \mathrm{m} \times 14-17 \mu \mathrm{m}$ dan 1.8, serta L. rubropurpurea 24-33 $\mu \mathrm{m} \times$ 13-17 $\mu \mathrm{m}$ dan 1.9. Lima galur L. theobromae dalam penelitian ini memiliki dimensi panjang $\times$ lebar dan $\mathrm{P} / \mathrm{L}$ konidium muda sebesar 13.5-25.7 $\mu \mathrm{m} \times 8.1-14.0 \mu \mathrm{m}$ dan 1.5-2.2, sedangkan konidium dewasa 15.4-23.6 $\mu \mathrm{m} \times$ 10.7-12.8 $\mu \mathrm{m}$ dan 1.4-1.9. Dengan demikian kelima galur tersebut walaupun cukup beragam namun masih termasuk satu spesies L. theobromae. Pendekatan morfometrika barangkali perlu dilakukan terhadap datadata morfologi dan struktur $L$. theobromae semacam ini untuk analisis yang lebih akurat dan pengambilan kesimpulan.

Pendekatan molekuler menggunakan teknik RAPD-PCR yang menggunakan primer arbitrary atau acak berukuran pendek yang mengamplifikasi sikuen komplemennya yang tersebar di sepanjang genom cendawan ini, saat ini dianggap kurang meyakinkan karena memiliki tingkat reprodusibilitas yang rendah, namun demikian hasil per pengujian individu mampu memberikan perbedaan profil RAPDPCR masing-masing galur yang ditunjukkan dengan perbedaan jumlah pita amplikon dan ukurannya. Sowmya et al. (2018) menggunakan teknik RAPD-PCR untuk sejumlah besar galur $L$. theobromae pada tanaman murbei dan berhasil menunjukkan keragaman yang nyata dan hasilnya sesuai dengan keragaman hayati yang ditunjukkan dari aspek pengujian patogenisitas. Hal ini juga memberikan petunjuk awal dan konfirmasi terhadap pendekatan secara morfologi di atas bahwa $L$. theobromae yang menginfeksi inang yang berbeda bisa jadi berbeda pada tingkat subspesies (intraspesies). Pendekatan molekuler yang lebih baik dapat menggunakan analisis hasil sikuensing nukleotida hasil PCR menggunakan primer yang mengamplifikasi wilayah internal transcribed spacer (ITS) dari gen ribosomal RNA atau analisis nukleotida hasil PCR yang mengamplifikasi wilayah beberapa gen secara multilokus misalnya gen translation elongation factor 1-alpha (tef1-a) seperti yang telah digunakan RodríguezGálvez et al. (2017) sebagai dasar filogeni dan penentuan patogenisitas spesies-spesies Lasiodiplodia pada tanaman mangga.

Lima galur cendawan patogen yang berasal dari lima tanaman inang, yaitu jeruk, kakao, karet, manggis, dan pisang masing-masing dari provinsi berbeda di Indonesia masih termasuk dalam satu spesies L. theobromae dan secara jelas menunjukkan keragaman intraspesies berdasarkan pertumbuhan vegetatif koloni, pembentukan, morfologi, dan ukuran struktur reproduktif piknidium dan konidium serta profil molekuler fragmen hasil RAPD-PCR.

\section{DAFTAR PUSTAKA}

Barkai-Golan R. 2001. Postharvest Diseases of Fruits and Vegetables: Development and Control. Amsterdam (NL): Elsevier Science BV. DOI: https://doi.org/10.1016/ B978-044450584-2/50002-2.

Bautista-Cruz MA, Almaguer-Vargas G, Leyva-Mir SG, Colinas-León MT, Correia KC, Camacho-Tapia M, Robles-Yerena L, Michereff SJ, Tovar-Pedraza JM. 2019. Phylogeny, distribution, and pathogenicity of Lasiodiplodia species associated with cankers and dieback symptoms of Persian lime in Mexico. Plant Dis. 103(6):11561165. DOI: https://doi.org/10.1094/PDIS06-18-1036-RE.

Burgess TL, Barber PA, Mohali S, Pegg G, de Beer W, Wingfield MJ. 2006. Three 
new Lasiodiplodia spp. from the tropics, recognized based on DNA sequence comparisons and morphology. Mycologia 98(3):423-435. DOI: https://doi.org/10.10 80/15572536.2006.11832677.

Febbiyanti TR, Widodo, Wiyono S, Yahya, S. 2019. Effect of $\mathrm{pH}$ and storage period to the growth of Lasiodiplodia theobromae which causes the stem canker on the rubber plant. Indones J Nat Rubber Res. 37(1):110. DOI: https://doi.org/10.22302/ppk.jpk. v37i1.615.

Goos RD, Cox EA, Stotzky G, 1961. Botryodiplodia theobromae and its association with Musa species. Mycologia 53(3):262-277. DOI: https://doi.org/10.10 80/00275514.1961.12017959.

Griffiths DA. 1967. Induced sporulation of Botryodiplodia theobromae Pat. isolated from Araucaria cunninghamii Ait. in Malaysia. Mycopathol mycol applic. 33(34):273-279. DOI: https://doi.org/10.1007/ BF02088919.

Kannan C, Karthik M, Priya K. 2010. Lasiodiplodia theobromae causes a damaging dieback of cocoa in India. Plant Pathol. 59(2):410. DOI: https://doi. org/10.1111/j.1365-3059.2009.02192.x.

Karunanayake KOLC, Adikaram NKB. 2020. Stem-end rot in major tropical and sub-tropical fruit species. Ceylon J Sci. 49(5):327-336. DOI: https://doi. org/10.4038/cjs.v49i5.7800.

Mohali S, Burgess TI, Wingfield MJ. 2005. Diversity and host association of the tropical tree endophyte Lasiodiplodia theobromae revealed using simple sequence repeat markers. For Pathol. 35(6):385-396. DOI: https://doi.org/10.1111/j.14390329.2005.00418.x.

Moller EM, Bahnweg G, Sandermann H, Geiger HH. 1992. A simple and efficient protocol for isolation of high molecular weight DNA from filamentous fungi, fruit bodies, and infected plant tissues. Nucleic Acids Res. 20(22):6115-6116. DOI: https://doi.org/10.1093/nar/20.22.6115.

Picos-Muñoz PA, García-Estrada RS, LeónFelix J, Sañudo-Barajas A, Allende-Molar
R. 2015. Lasiodiplodia theobromae in agricultural crops in México: taxonomy, host, diversity and control. Rev Mex Fitopatol. 33(1):54-74.

Punithalingam E. 1980. Plant Diseases Attributed to Botryodiplodia theobromae Pat. Lichtenstein $(\mathrm{CH})$ : J Cramer Pub.

Rodríguez-Gálvez E, Guerrero P, Barradas C, Crous PW, Alves A. 2017. Phylogeny and pathogenicity of Lasiodiplodia species associated with dieback of mango in Peru. Fungal Biol. 121(4):452465. DOI: https://doi.org/10.1016/j. funbio.2016.06.004.

Rossman AY, Allen WC, Castlebury LA. 2017. (2514-2516) Proposals to conserve Botryodiplodia theobromae (Lasiodiplodia theobromae) against Sphaeria glandicola, Diplodia gossypina, and Physalosporarhodina (Botryosphaeria rhodina); Phyllosticta yuccae against Leptodothiorella notabilis; and Ramularia brunnea against Sphaerella tussilaginis (Mycosphaerella tussilaginis) (Ascomycota: Dothideomycetes). Taxon. 66(3):747-748. DOI: https://doi. org/10.12705/663.17.

Salvatore MM, Andolfi A, Nicoletti R. 2020. The thin line between pathogenicity and endophytism: The case of Lasiodiplodia theobromae. Agriculture. 10(10):1-22. DOI: https://doi.org/10.3390/ agriculture10100488.

Sangchote R, Pongpisutta R. 1998. Fruit rots of mangosteen and their control. Di dalam: Proceedings of an International Workshop Disease Control and Storage Life Extension in Fruit. 1997 Mei 22-23; Chiang Mai (TH): ACIAR. hlm 81-86.

Slippers B, BoissinE, PhillipsAJL, Groenewald JZ, Lombard L, Wingfield MJ,Postma A, Burgess T, Crous PW. 2013. Phylogenetic lineages in the Botryosphaeriales: a systematic and evolutionary framework. Stud Mycol. 76:31-49. DOI: https://doi.org/10.3114/sim0020.

Sowmya P, Naik VN, Sivaprasad V, Naik VG. 2018. Characterization and correlation of pathogenicity of Botryodiplodia 
theobromae isolates, the causal agent of black root rot of mulberry (Morus spp.). Arch Phytopathol Plant Prot. 51(1920):1022-1038. DOI: https://doi.org/10.10 80/03235408.2018.1544192.

Vitoria NS, Cavalcanti M, Bezerra JL 2012. Lasiodiplodia theobromae: a new host and a revision of plant hosts reported in Brazil. Agrotrópica. 24(1):63-66.
DOI: https://doi.org/10.21757/01033816.2012v24n1p63-66.

Zhang J. 2014. Lasiodiplodia theobromae in citrus fruit (Diplodia stem-end rot). Di dalam: Bautista-Baños, editor. Postharvest Decay. Massachusetts (US): Academic Press. hlm 309-335. DOI: https://doi.org/10.1016/ B978-0-12-411552-1.00010-7. 